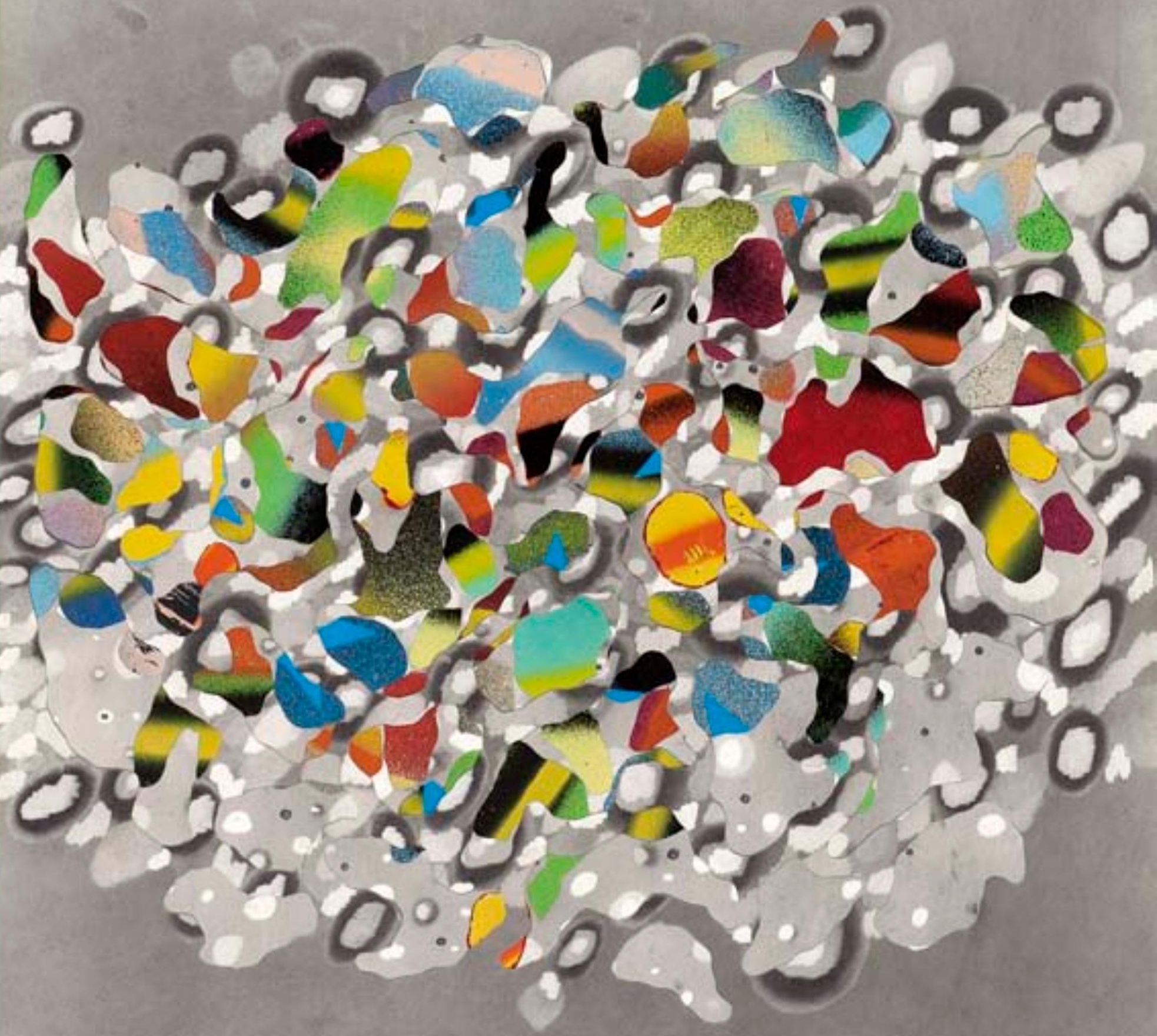




\title{
EL CÀNCER DE MAMA, AVUI AVENÇOS EN L'EPIDEMIOLOGIA DEL CÀNCER DE MAMA FEMENÍ
}

\author{
Marina Pollán SANTAMARÍa
}

\section{El càncer de mama és un problema de salut en la població femenina en tot el món. És tan freqüent que per a tots nosaltres té el rostre de familiars, amigues o conegudes. En aquest article comentem la situa- ció d’aquesta malaltia en el món i al nostre país, així com els principals factors de risc.}

Paraules clau: càncer de mama, incidència, mortalitat, determinants.

\section{EL CÀNCER DE MAMA AL MÓN}

Segons estimacions de l'Agència Internacional per a la Investigació del Càncer (IARC), anualment es diagnostiquen 1,44 milions de casos al món, la meitat dels quals en dones de països en via de desenvolupament. A Europa es diagnostiquen cada any més de 450.000 casos nous. Les diferències geogràfiques són menys marcades que fa unes dècades, però hi ha un clar patró geogràfic, amb major incidència als EUA, Europa i Austràlia (Ferlay et al., 2010)

En el segle Xx, el càncer de mama va mostrar un ascens en tot el món. Al començament del XxI s'observa un descens als EUA i en gran part dels països desenvolupats. Aquesta disminució es produeix principalment en dones més grans de cinquanta anys i està relacionada amb la caiguda en l'ús de la teràpia hormonal substitutiva en dones postmenopàusiques

La incidència a Espanya és inferior a la de països del nostre entorn, amb taxes ajustades de 61 casos per 100.000 dones-any, mentre que en la Unió Europea és de 77 per 100.000. Els canvis reproductius i socials en les dones espanyoles expliquen el fort increment del càncer de mama en les últimes dècades. Els programes poblacionals de garbellament en totes les comunitats autònomes en els anys noranta van contribuir a l'augment de casos diagnosticats en aquella dècada $i$ al descens al nostre país a començament del segle XXI. Les comunitats que van implantar abans el garbellament mostren que la incidència cau després de l'exhauriment de població susceptible de ser inclosa en el programa, per a estabilitzar-se o fins i tot tornar a augmentar posteriorment. Cada any es diagnostiquen 27.000 casos nous de càncer de mama en dones espanyoles (Sánchez et al. 2010).

Gràcies al diagnòstic precoç $\mathrm{i}$ als avenços terapèutics en la dècada de 1990 la mortalitat comença a descendir en el món desenvolupat. A Espanya, des de 1992 la mortalitat per aquest càncer disminueix un $2 \%$ anual. Actualment, les morts per aquesta causa (6.280 l'any 2010) representen el 3,4\% de la mortalitat general femenina al nostre país (Pollán et al., 2009).

\section{PRINCIPALS FACTORS DE RISC}

Com la majoria dels tumors, la freqüència d'aquest tipus de càncer augmenta exponencialment amb l'edat i descendeix després de la menopausa a causa de la disminució d'hormones circulants, ja que es tracta d'un tumor amb una gran dependència hormonal (Colditz et al., 2006)

\section{Factors hormonals i reproductius}

La menarquia primerenca i la menopausa tardana impliquen major exposició estrogènica i n'incrementen la incidència. No tenir fills o l'edat tardana del primer embaràs representen un retard en la maduresa glandular, la qual cosa augmenta el risc de patir aquest càncer. L'embaràs té un doble efecte a curt i llarg termini: la gestació augmenta el nivell d'hormones circulants, que en si mateix constitueix un factor de risc, però la finalització de l'embaràs representa la maduració de la glàndula mamària. Les dones sense fills tenen menor 


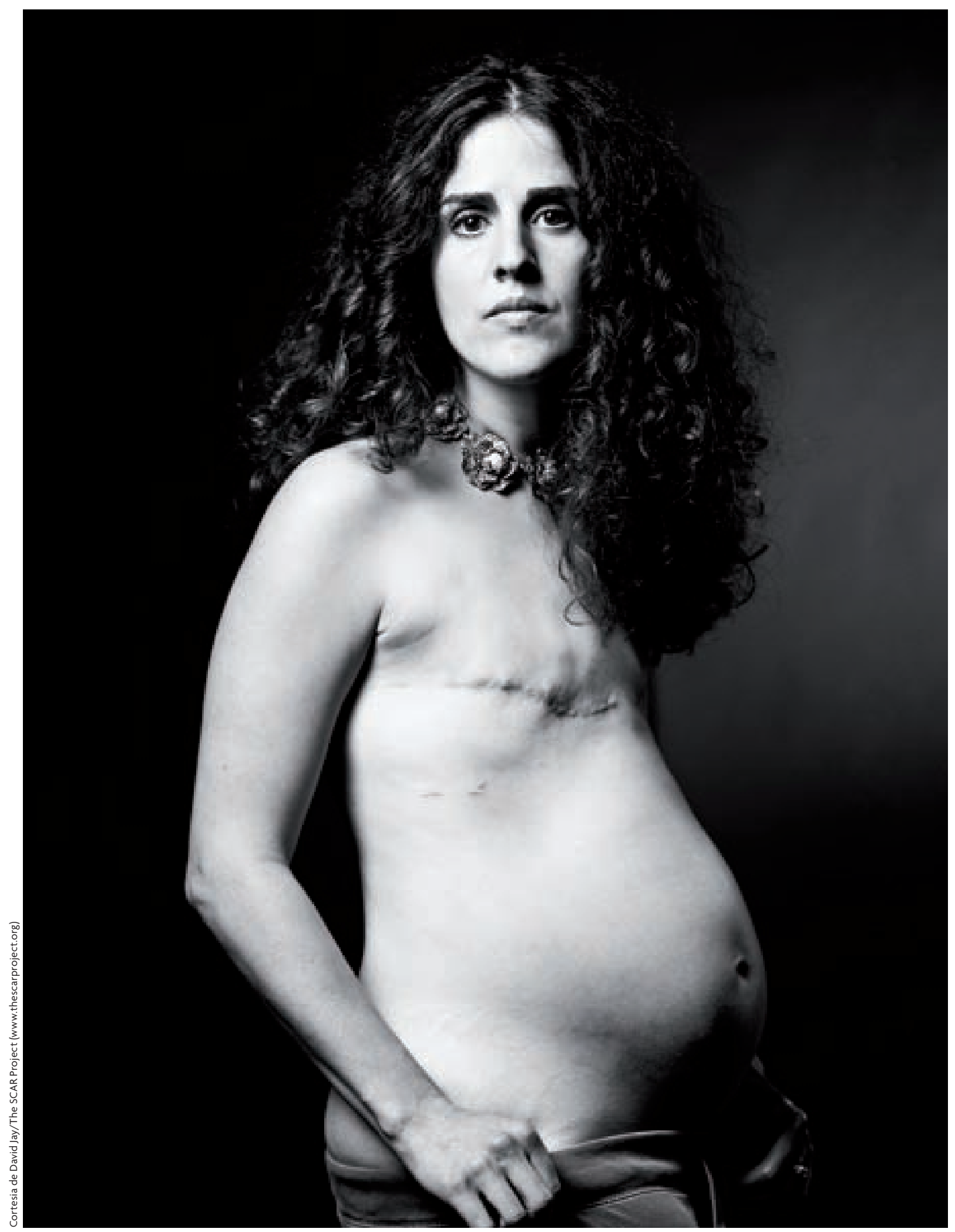

L'embaràs té un doble efecte a curt i llarg termini: la gestació augmenta el nivell d'hormones circulants, que en si mateix constitueix un factor de risc, però la finalització de l'embaràs representa la maduració de la glàndula mamària. Les tres fotografies que il-lustren aquest article pertanyen al Projecte SCAR del fotògraf David Jay, que pretén mostrar el càncer sense ornaments artificials. 
incidència d'aquest tumor en edats joves i l'excés de risc en nul-lípares és inferior a l'observat en dones el primer part de les quals és tardà. L'alta paritat i l'ovariectomia primerenca són factors protectors

Les concentracions en sang d'estrògens i testosterona es correlacionen positivament amb la freqüència del tumor. S'ha descrit una correlació positiva amb les concentracions circulants d'IGF-1 o factor de creixement insulinoide I o somatomedina C (Key et al., 2010).

Els anticonceptius orals augmentarien el risc, les usuàries són dones joves i l'excés de risc desapareix en cessar el tractament, per la qual cosa l'efecte global és escàs. La teràpia hormonal substitutiva és més important, car es consumeix en un moment de la vida en què l'aparició del tumor és més freqüent. La teràpia combinada, tractaments de llarga durada (cinc anys o més) i l'inici durant o immediatament després de la menopausa representa major risc.

\section{Antecedents familiars i susceptibi- litat genètica}

Un familiar de primer grau amb càncer de mama duplica el risc de patir-ne, la qual cosa mostra la contribució dels factors genètics. L'aparició de diversos casos de càncer de mama en la mateixa família és deguda de vegades a la presència de mutacions amb alt impacte (mutacions d'alta penetrància). Els principals gens implicats són BRCA1 i BRCA2, P523 i PTEN. També s'han descrit gens de moderada penetrància, com CHEK2, BRIP1 i PALB2.

En la major part dels casos, la

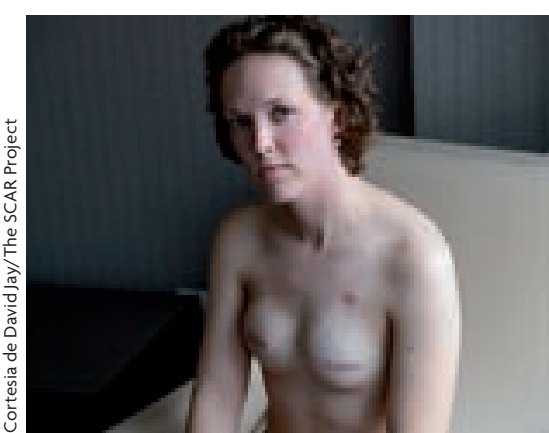

"UN FAMILIAR DE PRIMER GRAU AMB CÀNCER DE MAMA DUPLICA EL RISC. L'APARICIÓ DE DIVERSOS CASOS DE CÀNCER DE MAMA EN LA MATEIXA FAMÍLIA DE VEGADES ÉS DEGUDA A LA PRESĖNCIA DE MUTACIONS AMB ALT IMPACTE»

\section{Antecedents personals}

La patologia mamària benigna augmenta el risc de desenvolupar un tumor maligne, particularment si es tracta de lesions proliferatives amb atípies. El carcinoma ductal in situ constitueix una lesió maligna preinvasiva, mentre que el carcinoma lobullar in situ seria una lesió precursora.

La diabetis tipus II i la síndrome metabòlica també incrementen el risc de càncer de pit. Part de l'excés de risc és degut a l'obesitat, que s'associa amb aquestes síndromes.

Obesitat, activitat física i factors dietètics

L'obesitat i el guany de pes en l'edat adulta augmenten el risc de càncer de mama en dones postmenopàusiques. El seu teixit adipós és la principal font d'estrògens. L'activitat física actua com a factor protector.

La dieta inclou substàncies canminada per variants més freqüents l'efecte de les qual és modest i que, conjuntament, conformen la susceptibilitat individual. Grans estudis collaboratius estan permetent identificar gran nombre de variants. El càncer de mama és una malaltia complexa, per interacció entre factors genètics i ambientals.

\section{Factors de risc prenatals}

El pes del bebè en el naixement i l'edat avançada de la mare augmenten el risc de desenvolupar aquest tumor, la qual cosa tradueix l'efecte de l'exposició hormonal intraúter. L'estatura de la dona adulta es considera un marcador global de factors genètics, hormonals i nutricionals i mostra una correlació positiva amb la inci- cerígenes i anticancerígenes. És difícil aïllar l'efecte d'un únic nutrient, molts estan correlacionats. Aquestes dificultats expliquen l'escassesa de factors dietètics associats de manera consistent al càncer de mama. L'únic nutrient clarament associat és el consum d'alcohol. El sucre i els carbohidrats d'absorció ràpida podrien augmentar el risc incrementant els nivells d'insulina i IGF-1. Els resultats dels estudis sobre consum de greixos també són heterogenis, els àcids grassos poliinsaturats i els greixos trans, presents en aliments processats que contenen olis hidrogenats (margarina, brioixeria industrial) n'augmenta el risc, mentre que l'alt consum d'àcid omega-3 i el consum d'oli d'oliva actuen com a protectors. La 
carn roja també augmenta el risc, mentre que el consum de fibra el disminueix.

La soja i altres aliments contenen compostos amb dèbil activitat estrogènica que poden interferir en l'acció i el metabolisme dels estrògens endògens. Els estudis experimentals i epidemiològics ofereixen resultats a vegades contradictoris. L'efecte protector s'observa només en dones asiàtiques, amb consums molt elevats d'aquests aliments durant la infantesa i adolescència.

La vitamina D inhibeix el creixement de les cèllules tumorals en estudis experimentals. La concentració de vitamina $\mathrm{D}$ depèn de la ingesta $\mathrm{i}$ de l'exposició solar. Diversos estudis suggereixen un efecte protector, però els resultats de moment no són consistents. L'àcid fòlic participa en el metabolisme i síntesi de l'ADN. Alguns estudis en població amb baix consum de folats han mostrat una relació inversa entre els nivells d'àcid fòlic i la incidència de càncer de mama.
L'estudi de «patrons dietètics» ofereix una alternativa per a investigar la influència de la dieta. Hom pensa que el patró dietètic occidental poc saludable (alt consum de carn, aliments processats amb alt contingut en sucre i greixos saturats i trans) augmenta la frequiència de càncer de mama, mentre que la dieta saludable (dieta mediterrània amb alt consum de fruita, verdura, peix i oli d'oli-

va) sembla disminuir aquest risc.

Altres factors de risc: factors ambientals i ocupacionals La radiació ionitzant és capaç de desencadenar un càncer de mama si l'exposició ocorre en els primers anys de vida, adolescència o embaràs, quan la glàndula mamària està desenvolupant-se. Les fonts de radiació ionitzant estudiades inclouen les radiografies i la radioteràpia.

Els estudis en animals de laboratori han identificat més de 200 carcinògens mamaris, l'evidència en hu-

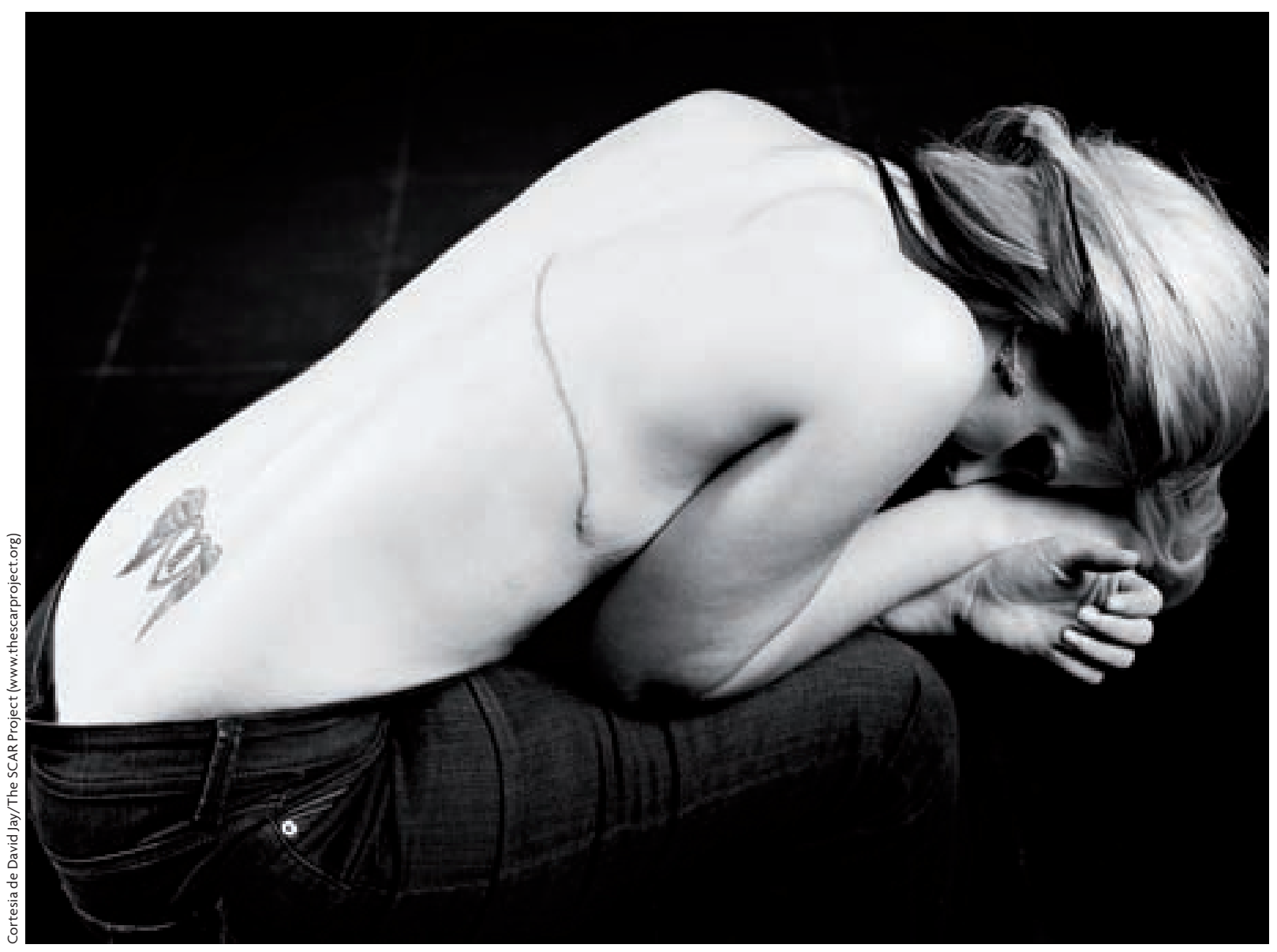




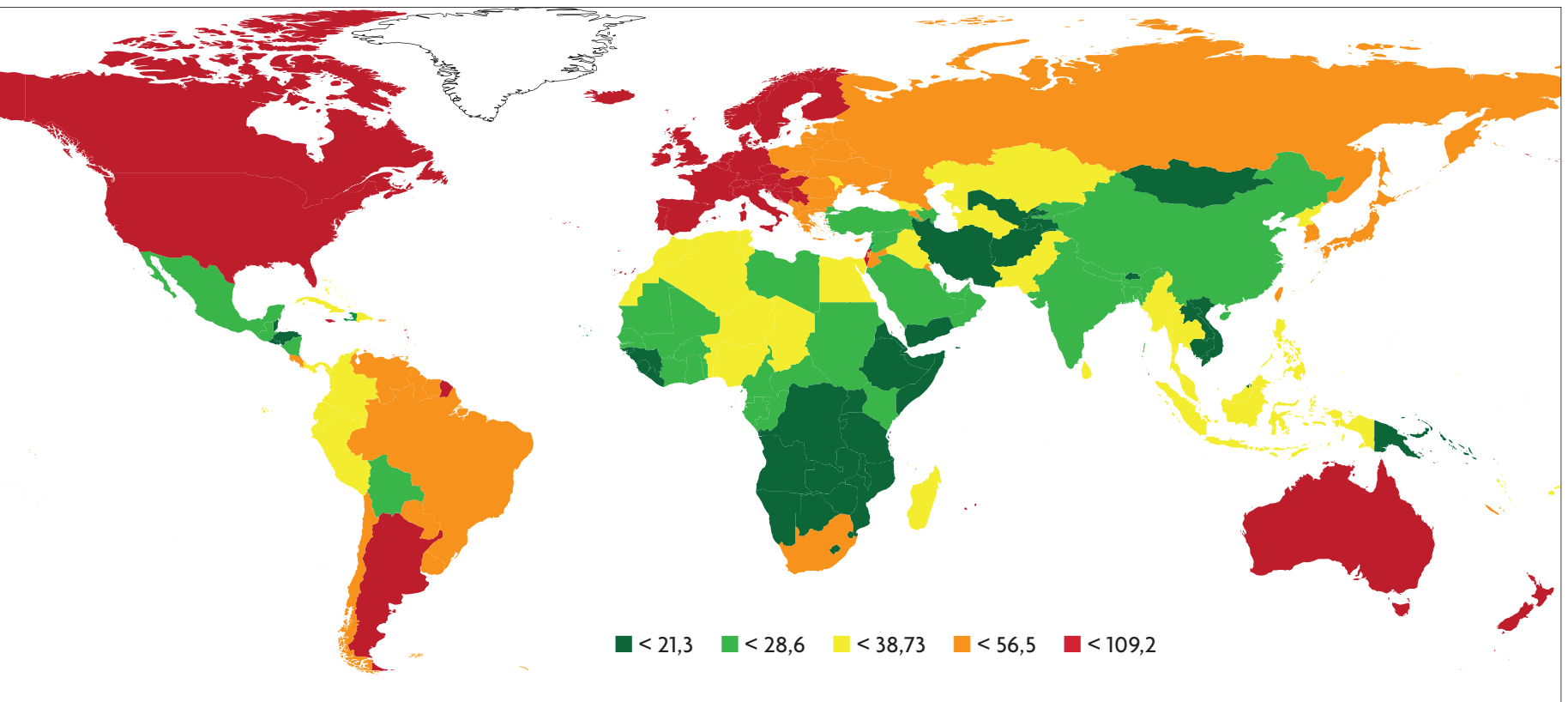

Distribució de la incidència de càncer de mama al món. Taxes estandarditzades per edat: casos per 100.000 dones-any.

mans és més escassa i l'excés de risc atribuït a determinats plaguicides, solvents i disruptors endocrins no està prou establert.

Quant a factors professionals, s'associa major incidència de càncer de mama en secretàries, professores, treballadores sanitàries, de la indústria química i farmacèutica, telefonistes-telegrafistes i perruqueres. Les persones que treballen de nit pateixen una alteració del ritme circadiari, que implica la disminució o supressió en la secreció de l'hormona melatonina. Estudis en animals d'experimentació abonen una relació entre la disrupció del ritme circadiari i l'augment de càncer de mama, l'evidència en humans és encara limitada (Pollán, 2001).

\section{QUÈ PODEM FER PER A DISMINUIR EL RISC?}

Actuar sobre els factors reproductius no és fàcil. La fertilitat a Espanya ha disminuït i l'edat del primer part ha augmentat. A pesar que determinades ajudes socials poden fomentar la natalitat, no és realista plantejar un canvi dràstic en el patró reproductiu, subjecte a condicionants socials i professionals. A Espanya, com en altres països desenvolupats, l'edat de la menarquia s'ha avançat.

En l'adult, evitar l'obesitat, fer exercici físic de manera regular i reduir o evitar el consum d'alcohol contribueix a prevenir el càncer de mama i altres malalties. Respecte a recomanacions dietètiques concretes, tot $\mathrm{i}$ que no hi ha prou evidències, sembla sensat proposar la reducció del consum de carn roja, greixos animals, ali- ments processats i aquells amb alt contingut en sucre, i fomentar el consum de fibra, peix i oli d'oliva verge. Aquest missatge és pertinent davant de l'empitjorament del patró dietètic que s'observa en les dones més joves. L'obesitat és un problema en augment en tot el món. A Espanya, el 28\% de les dones que acudeixen als centres de garbellament de càncer de mama són obeses.

Totes les comunitats autònomes disposen de programes poblacionals de diagnòstic precoç de càncer de mama, seguint les recomanacions de les guies europees de garbellament. L'objectiu és detectar els tumors en estadis més precoços per tal de millorar les possibilitats terapèutiques i el pronòstic a llarg termini. ()

BIBLIOGRAFIA

Colditz, G. A. et al., 2006. «Breast Cancer». In Schottenfeld. D. i J. F. Fraumeni (eds.). Cancer Epidemiology and Prevention. 3 ed. Oxford University Press. Nova York.

FERLAY, J. et al., 2010. Globocan 2008, Cancer Incidence and Mortality Worldwide. International Agency for Research on Cancer. Lió.

Key, T. J. et al., 2010. «Insulin-like Growth Factor 1 (IGF1), IGF Binding Protein 3 (IGFBP3), and Breast Cancer Risk: Pooled Individual Data Analysis of 17 Prospective Studies». The Lancet Oncology, 11(6): 530-542. DOI: <10.1016/S1470-2045(10)70095-4>.

Pollan, M., 2001. «Breast Cancer in Women and Occupation. A Review of the Evidence». Gaceta Sanitaria, 15(4): 3-22.

Pollan, M. et al., 2009. «Recent Changes in Breast Cancer Incidence in Spain, 1980-2004». Journal of the National Cancer Institute, 101(22): 1584-1591. DOI: <10.1093/inci/dip358>.

SÁncheZ, M. J. et al., 2010. «Cancer Incidence and Mortality in Spain: Estimates and Projections for the Period 1981-2012». Annals of Oncology, 21(3): 30-36. DOI: <10.1093/annonc/mda090>.

Marina Pollán Santamaría. Epidemiòloga, cap de servei d’Epidemiologia del Càncer en l'Àrea d'Epidemiologia Ambiental i Càncer, Centro Nacional de Epidemiología (Instituto de Salud Carlos III), Madrid. 